\title{
The Reputations of Mary Queen of Scots
}

Jayne Lewis

\section{(2) OpenEdition \\ Journals}

Electronic version

URL: http://journals.openedition.org/etudesecossaises/146

ISSN: 1969-6337

Publisher

UGA Éditions/Université Grenoble Alpes

Printed version

Date of publication: 31 March 2005

Number of pages: 41-55

ISBN: 2-84310-061-5

ISSN: 1240-1439

\section{Electronic reference}

Jayne Lewis, "The Reputations of Mary Queen of Scots », Études écossaises [Online], 10 | 2005, Online since 31 March 2005, connection on 07 September 2020. URL : http://journals.openedition.org/ etudesecossaises/146

(ㄷ Études écossaises 
Jayne Lewis

\section{The Reputations of Mary Queen of Scots}

\author{
Talked of poor Mary of Scots'execution, which \\ M. said Elizabeth delayed too long, for that \\ her Ministers had been urging it. [...] Talked \\ of poor Mary. «She was a bad woman,» said \\ Lord M., "she was a silly, idle, coquettish \\ French girl». I pitied her. Diary of Queen \\ Victoria. (Friday, 12 July 1839)
}

JAYNE LEWIS University of California, Irvine.
As reputations go, that of Mary Queen of Scots was never an especially Scottish one. Nor does it appear ever to have been very good. Bred in the permissive Renaissance court of the Valois king, Henri II, this «silly, idle, coquettish French girl» was branded a harlot by many of her own Scottish subjects (Esher, 1912, i, p. 219). She was suspected of complicity in the murder of her second (English) husband, then accused of adultery with the man who soon became her third, and at whose side she waged war on many of her own people. When Mary was so famously beheaded, in England, in the winter of 1587, it was for plotting to kill her cousin once-removed, Elizabeth Tudor. How on earth could anyone have «pitied her »? And yet, from another point of view, Mary's reputation could hardly be better : she died a self-proclaimed martyr to her Roman Catholic faith, after nineteen years of captivity that won the sympathy even of some of her English captors. Her brief, disastrous personal rule in Scotland has shown many historians a gentle and tolerant spirit ill-equipped for the Realpolitik of a determined Protestant ascendancy. Her virtually life-long separation from her only child, James VI of Scotland and I of England, is poignant, her generous affection for the women who cared for her legendary (Donaldson, 1983; Lynch, 1988; Wormald, 1988).

The cultural value of «reputation» would appear to lie in its ability to assign stable meaning to its referent, which assignment produces collective understanding and guarantees the symbolic transmission through time that further binds groups 
together. Yet Mary Queen of Scots seems born to expose the frailty of «reputation» as a stable sign, and thereby to frustrate the twin possibilities of social coherence and historical persistence. Even in her own day, she was visible only through conflicting, indeed contradictory images, each of which so noisily trumpeted both its truth to life and its bid to compel monolithic response that it revealed in the end little more than its own ideological construction (Phillips, 1964). For every Protestant who saw Mary as a bloodthirsty harlot there was thus a Catholic to see her as a pious martyr. For every Scottish person who had heard she was a Frenchified interloper, there was a French one who understood her to be the rightful unifier of the thrones of England, Scotland, and France. For every man who loathed and repudiated her as a Jezebel, there was a woman to love her as a composite of the biblical Marys who participated in Christ's passion.

As it maps onto an enduring system of binaries - religious, geopolitical and gendered - the war of reputations around Mary would seem to guarantee her invisibility as anything other than a political sign, one whose crude transparency robs it of any of the authority it was contrived to wield. Not coincidentally, from a strictly iconographic point of view, contemporary visual images of the Queen of Scots also lack consistency and referential authority. Of the several portraits of Mary that were painted in her own lifetime, that is, none really resembles any of the others: the most accurate may indeed be Francois Clouet's so-called «White Deuil» portrait, which shows a very young Mary's unremarkable face dissolving into the riddling mists of a snowy veil of mourning for her first French husband (Smailes \& Thomson, 1987, p. 30-31). Strong disagreements among the remaining contemporary portraits of the Queen of Scots drove Walter Scott, over 200 years after her demise, to exaggerate the case, lamenting that «there are no absolutely undoubted originals of her» only «innumerable copies» which leave Mary «as unfortunate in this as in other particulars of her life » (Anderson, 1977, p. 3). Two late Victorian critics rightly accepted some of the Renaissance portraits as authentic, but wished that «the crayon of Holbein might have given expression» to Mary's face, unleashing «the self-betrayal of personality» and saving future viewers the trouble of having to fill in the blanks (Bradley \& Cooper, 1890, p. v). 
Of course, the authority of real presence is an invention of romantic modernity, one that has come undone in postmodern representations of Mary like Liz Lochhead's drama of 1992, Mary Queen of Scots Got Her Head Chopped Off, where, the play of discrete, inscrutable personae - servant, Scottish schoolgirl, French dowager - is presented as Mary's essence. Structurally, the only difference between Lochhead's Queen of Scots and her sixteenth-century counterpart is that in the sixteenth century Mary's various masks were split between competing political camps. For instance, one of the most notorious contemporary representations of Mary was a cartoon depicting her as a mermaid that made the rounds among the Queen of Scot's enemies as they wrestled her from her Scottish throne. The image literally replaced the adulatory French portraits of «la reine dauphine» that multiplied during her girlhood and brief marriage to the French crown prince, Francois II, dumping Mary's image from the echelons of courtly art to the streets of Edinburgh, where the mermaid flew on many a militant banner. Just so the last known portrait of the living Mary (made during her English captivity) survives in two versions: in one (the work of an English artist), Mary's sharp features and wary, slanting eyes connote craft and threat; a crucifix glints like a dagger just below her breast (Smailes \& Thomson, plate 32). After Mary's execution, however, one of her women in waiting commissioned a revision of this same portrait. In the new version (Smailes \& Thomson, p. 54-56) the queen's face is rounded and gentle, the crucifix raised as if to scatter benediction. Similarly, we have inherited two very different pictures of Mary at the hour of her death. One is verbal and comes courtesy of the English Protestant Robert Wyngfield, who witnessed her execution and painted her as a lascivious carnival queen, tricked out in «borrowed hair» garish green and crimson silk, and frivolous «boots of Spanish leather ». When this vain, manipulative Mary's head was finally severed, Wyngfield gleefully reported, «her dressing of lawn fell from her head, which appeared as if she had been seventy years old, polled very short, her face being in a moment so much altered from its form when she was alive, as few could remember her by her dead face» (Wyngfield, 1884-1886, i, p. 11). Yet almost immediately after Mary's death a very different portrait, this one visual rather than verbal, circulated in Catholic Europe. In Robert Verstegan's book of saintly 
martyrdoms, Theatrum Crudelitatum (1587), an almost maidenly Mary kneels in sacrificial innocence, one gash already marring her neck to announce the executioner's exorbitant cruelty (Petti, 1959-1960).

This division in Mary's contemporary reputation is gruesomely literalized in the fate of her body, since the headsman's axe was meant not just to sever her body in two but to separate Mary definitively and permanently from her better reputation. Her mortified body was meant to prove that she was a very «bad woman» indeed, and that there were no two ways about it. But the execution was botched: it took the executioner three strokes to finish the job (leaving, as Wyngfield put it, «a little gristle behind») and when he was done Mary was merely ready for her afterlife in Catholic and continental propaganda against English Protestant barbarism. Wyngfield himself reported the grotesque detail that Mary's «lips stirred up and down almost a quarter of an hour after her head was cut off» and though Wyngfield intended this as a parodic, demeaning detail, it also « speaks » to Mary's endurance as a cultural icon (Wyngfield, i, p. 13). For though both the Scots and the English so often repudiated her in her lifetime, Mary's tomb is today one of Westminster Abbey's most popular attractions, and Mary's bedchamber at Holyrood House enjoys a similar status in Edinburgh, as do the ruins of the castle on Lochleven where she was forced to sign away her throne, where she allegedly gave birth to stillborn twins, and whence she escaped, disguised as a laundress. At the popular Mary Queen of Scots House in the border town of Jedburgh, pencils and paperweights proclaim her sovereignty in the kingdom of present-day tourism. Such shrines and icons merely summarize over four centuries of literary and artistic involvement with Mary's memory. Again and again, novels, poems, plays, paintings, and music have all resurrected the Queen of Scots for private consumption and collective scrutiny, and in both of these registers there is little disagreement between English people and Scots, women and men, Catholics and Protestants, that she is worthy of such attention.

Through all of this, reputation has continued to matter whenever, as Victoria put it, people «tal [k] of poor Mary». Beside every «bad woman» a good one still stands, and viceversa. In attempting to understand how this bifurcation could persist, and what its consequences and significance might be, 
I want to propose that because rival public images cancel one another out, exposing each other as mere signs of political contest, they create room for a drastically different order of response, one that seems to belong less to the mess and contingency of history than to the seeming (if to some extent always illusorily) autonomous realm of art. As the poet Joseph Brodsky put it, "there's nothing, barring Art, sub lunar creatures/can use to comprehend [her] gorgeous features ». Brodsky adds, significantly: «leave history to good queen Bess » (Brodsky, 1991, p. 22).

Second, though, I want to suggest that Mary's place beyond reputation was less a utopia outside history than one in which the human reality of lived history and those areas of fantasy and desire that seem to lie outside history actually converge. This is perhaps most visible in the modern sub-genre of historical fiction, whose aspirations she virtually embodies, and whose favorite heroine, from Walter Scott to Jean Plaidy, she has long been. In any event, Mary cannot be said merely to have been driven from political history into private romance or pure «Art». She is, rather, a key to understanding the enduring if evolving relationship between these two, improperly dichotomized, realms of ego investment and cultural activity.

Elizabeth herself described Mary as «the daughter of debate, that eke discord doth sow» and as J.E. Phillips was the first to show, every event in Mary's life up to and including her death was represented and interpreted from radically opposing points of view, depending on the political passions and desires of whoever happened to be interpreting or representing them. The schism was charted and exemplified in the differences between the Protestant George Buchanan and the Catholic Bishop of Ross, John Leslie. Buchanan's virulent Detection of the Douings of Marie was published shortly after Mary's abdication and denounced her «unnaturalness, hatred, barbarous fierceness [and] outrageous cruelty» (Buchanan, 1721, p. 57). In the inflammatory view of the man her rebellious Protestant subjects hired to hold it, Mary is a «poisoning witch» who not only killed her second husband but took wanton pleasure in the spectacle: «As she had satisfied her heart with his slaughter, so she would needs feed her eyes with the sight of his body slain» Buchanan wrote. «For she long beheld, [...] with greedy eyes, 
his dead corps» (Buchanan, p. 27). By contrast, the Catholic Bishop John Leslie made Mary the pious and long-suffering heroine of his Defence of the Honour of [...] Marie (1569). Here, Mary could not be farther from Buchanan's poisoning witch. Instead of a bloodthirsty and lascivious wife, she is a «most careful, tender mother with all» whose «godly and virtuous life past, do far repel and drive away all suspicion» (Leslie, 1569, p. 6). Both Buchanan and Leslie used narratives about Mary to support arguments about the legitimacy of female rule and about the desirability of a Catholic monarchy; their images of her are as extreme as their difference of opinion on these points, and indeed the contending reputations they forged for the Queen of Scots are alike in that both are most legible as icons of political passion. But they are also tokens of artistic power on the power of each verbal portraitist, and in this likeness a strange coherence of purpose - indeed of ego investment - may be discerned. Be it that of «poisoning witch» or «tender mother» that is, Mary's reputation tells us little about her, but everything about the beliefs and interests of Buchanan and Leslie - interests which converge, it must be said, in the desire to master Mary's reputation and its attendant imageries.

Though in subsequent eras politics did not revolve around the question of the legitimacy of female rule, the rival Marys created by Buchanan and Leslie persisted, and continued to map themselves onto partisan lines, particularly in England. Under her descendants, the star-crossed Stuarts who came to the throne with James, Mary was thus rehabilitated in proStuart propaganda as the wronged and sainted mother of the line - a «sad and most illustrious pattern of all Misfortune» whose destiny was so sadly repeated in the beheading of her grandson, Charles I (Camden, 1636, p. 661). But in the turbulent seventeenth century Buchanan's virulent Detection was also reprinted to justify Puritan revolt against the Stuarts. Then, in the eighteenth century, with the Stuarts off the throne, Mary became the heroine of an emerging, bourgeois sentimental culture. Waxwork models of her execution were erected and wept over in middle-class parlors, and popular romantic accounts of her life were translated from the French to become best-sellers (Haywood, 1725). Jacobite biographers and historians drew on both. They urged a widening circle of readers, all newly inclined to affective and identificatory 
reading to give Mary the benefit of every doubt, and painted new and melting pictures of her inarguably sad life. Particularly up to 1745 , these were often thinly veiled pleas for the return of the ousted Stuarts (Goodall, 1754; Tytler, 1759; Robertson, 1759; Hume, 1778).

An emergent sexual politics organized around the idea of the distinctively British woman also drafted Mary into its controversies. Newly popular memoirs of Britain's «illustrious women» like George Ballard's in 1752, drew verbal portraits of Mary that demonstrated her «stric [t] obedience and most obliging behaviour toward her husband» along with her "peculiar sweetness of temper and incomparable address" (Perry, 1985, p. 171). Mary stands as a model for a new, bourgeois femininity. At the same time, though, a skeptical enlightenment historiographer like David Hume could become famous for bellowing into the ear of a drunken colleague that «queen Mary was a whore» (Chambers, 1835, ii, p. 453). And in short order, inspired by the French Revolution, feminist historians like Mary Hays and Anna Jameson were seeing in the Queen of Scots the unbridled exercise of female desire - an embodiment of what Jameson called «the true feminine idea of empire, viz., the privilege of saying je le veux» (Jameson, 1832, p. ix). As for the Victorians, the popular nineteenth-century historian Agnes Strickland insisted that Mary embodied the most pious " charities and instincts of woman's nature " (Strickland, 1844, ii, p. 130). Indeed, Strickland's popular and novelistic biography of Mary enshrined the Queen of Scots as the prototype of the Victorian angel in the house. Yet to Strickland's no less popular contemporary, James Anthony Froude, Mary was a «wild cat» full of «cynical proficiency» and «sustained and elaborate artifices» wholly given over to her own "power of gratifying hersel» (Froude, 1862, xii, p. 360). Strickland, Froude, and equally engaged Victorians like Algernon Charles Swinburne were no longer exercised about Jacobites or Jacobins, but Mary was still useful in mapping contradictory beliefs about female cultural authority and the nature of empire.

We can in other words follow the Buchanan/Leslie dichotomy through the history of British writing about Mary Queen of Scots with very little trouble indeed. If we did so, we might conclude that that debate's ability to change shape according to prevailing political controversies - to the political binary $d u$ 
jour - is what kept the woman at its center in some manner alive. This is of course to see the matter very much from the point of view of the author, or artist, whose political opinions and cultural attitudes Mary's reputation simply reflects and potentially legitimates. But it is also to assume that very little changed in British symbolic practice over several centuries: that Mary's reputations were always mere puppets of ideology. Above all, it is to leave out those who looked at the visual portraits of Mary, and read the literary ones. While we've seen that the Queen of Scots herself is necessarily absent from her own reputation and the pictures that promulgate it, and while we've seen that those who represented her were overwhelmingly present, we haven't yet considered those who « consumed » her reputation and image. Yet they are part and parcel of the idea of Mary Queen of Scots, and - suspended between opposing reputations - they are in fact the key to that idea's persistence through history.

A graphic example of the fusion of image and reception reputation and interpretation - is the half-posthumous memorial portrait (Smailes \& Thomson, p. 54-56) in which Mary's mourning waiting women actually appear in the frame and reach into the portrait to touch her dress. The painting indeed adds historical events, including Mary's execution, that occurred subsequent to the painting of the central portrait. It thus incorporates temporality as well as subjectivity into the usually strictly spatial fixity of the queen's image. Here indeed we might recall Queen Victoria's exchange with her Prime Minister, Melbourne. Remember that when Melbourne invoked Mary's reputation as a «bad woman» Victoria did not counter that she was rather a good one but only said, «I pitied her.» Indeed, we don't know whether she said this at all, or only thought it. It doesn't matter. The point is that Victoria's pity is not necessarily a defense of Mary, a flinging of Leslie's «tender mother» in the face of Buchanan's «poisoning witch». Victoria incorporated the memory of rival reputations but out of them generated an entirely different kind of response - pity - whose structure makes the respondent (here, Victoria) part of the figure to which she responds. She thus grounds that figure in a specific historical moment, even as she is projected beyond it.

Significantly, Victoria and Melbourne were discussing Mary's execution, «which Lord M. said Elizabeth delayed too 
long ». Indeed, Mary's beheading was controversial, inadvertent, and botched, and as Jane Austen playfully pointed out in her History of England, it was the event that came closest to giving Elizabeth herself a reputation - and a very bad one too. Elizabeth did, famously, delay the execution, knowing full well the political support her kinswoman enjoyed. Though it may well have been staged for political gain, Elizabeth's ambivalence has been written into many subsequent representations of Mary herself, where it has been given the modern turns of pity and identication. Witness John Banks's durable 1686 tragedy about Mary, The Island Queens, Schiller's Maria Stuart, Donizetti's Maria Stuarda, and of course the Vanessa Redgrave film, Mary Queen of Scots (1972), all of which include in their portraits of Mary an other's complicating, complicated response to her.

For a historical figure of enduring (if dichotomous) repute, Mary is largely lacking in iconic accessories, but if there is one exception, it is the «dressing of lawn» Wyngfield noticed on her head as she knelt at the scaffold, a version of the same veil of mourning Clouet gave us. Prominent in the Renaissance portraiture, this headpiece appears again and again in later, perforce imaginative depictions of the queen. In the eighteenth century, it became a frilled mourning cap like the one we see in David Hume's influential History of England (Lewis, 1998, p. 128). It was the one indispensable feature of the popular Mary Queen of Scots masquerade costume of the same era, and women who indulged in the long-lived fashion of having themselves painted as Mary likewise always made sure to adopt it (Lewis, ch. 6). Most of the many nineteenth-century history paintings that featured Mary retain some version of the cap, or of Clouet's mystifying white veil. Yet the head dress is an odd icon for a queen. Surely a crown would be more appropriate. In Gavin Hamilton's 1776 painting of Mary's abdication, indeed, the crown is being relinquished but the cap remains. Hamilton thus inscribes the queen in a myth of private emotion, one that invites her viewer's identification, even as the Scottish artist subtracts her from a divisive myth of political influence and agency (Lewis, p. 114).

This is, in a very important sense, to remove Mary from the fray of rival reputations. It is a disarmingly modern move, one not fully conceivable before the eighteenth century, which is just when private women began dressing like Mary and writing 
poetry in which they assumed her voice, while male historians translated her love letters, and male poets forged new ones (Campbell, 1824). It was toward the end of this time that Walter Scott supposed that the disparities built into Mary's reputation (and captured in so many visual images of her) actually produce a different order of coherence, one that oddly delivers the Queen of Scots from the interminable, if charged, back and forth of mere reputation.

Scott's personal fascination with Mary's face led him to keep a drawing of her «head cut off and lying in a dish » on his wall at Abbotsford, and to put her at the center of his 1829 novel, The Abbot, which work was to inspire numerous nineteenth-century paintings of Mary and stage dramatizations of her life (Bolton, 1992, p. 375-393). Early in The Abbot, Scott's narrator supposes that although there are indeed so many competing pictures of the Queen of Scots:

amidst their discrepancy, each possesses general features which the eye at once acknowledges as peculiar to the vision which our imagination has raised while we read her history for the first time, and which has been impressed upon it by the numerous prints and pictures we have seen. Indeed, we cannot look on the worst of them [...] without saying that it is meant for Queen Mary; and no small instance it is of the power of beauty that her charms should have remained the subject not merely of admiration, but of warm and chivalrous interest, after the lapse of such a length of time. (Scott, 1820, ii, p. 181)

In the very multiplicity of detached, detachable, and thus so often contradictory «pictures» of Mary that have accumulated (and continue to accumulate) over time, a different order of coherence, continuity, and even identity emerges, one that begins in historical assessment of Mary's openly unreliable reputation, but quickly transcends it. Scott's novel presents Mary through the eyes of an ambivalent boy of the Borders who becomes her valet while she languishes in Lochleven. Not without regret and a kind of proleptic nostalgia that stands as both a historical and a fictive mirror for Scott's own, he watches her give up her crown to become a queen of sentimental historical fiction, safely ensconced between the leaves of a novel. But in becoming such a queen, Mary mirrors the still historical and political beings who, like Scott and his hero, have such ambivalent responses to her, and reminds of their own place in history. 
The Abbot was neither the first nor the last historical novel to feature Mary Queen of Scots, and in closing - as well as in hopes of illustrating more clearly the place beyond reputation that Mary actually occupies - I'd like to look at Scott's most important predecessor. The English novelist Sophia Lee's three-volume fiction, The Recess; or, A Tale of Other Times was published between 1783 and 1785, which is to say almost exactly midway between Mary's death and the present day. Lee's best-selling, oft-reprinted novel features two heroines, twin sisters of the Elizabethan age who have been brought up in secret. Their clandestine home, the «recess » of Lee's title, is the cellar of a ruined abbey, their surrogate mother a governess, one Mrs. Marlow. One day, the twins accidentally stumble across a «whole-length pictur [e]» which «represented a lady in the flower of youth, drest in mourning, and seeming in every feature to be mark'd by sorrow; a black veil half-shaded a coronet she wept over» (Lee, 1786, i, p. 20). Though they do not know who the «lady» is, the twins find themselves weeping too. Their tears inspire their guardian to tell them that the lady stripped of political power is Mary Queen of Scots, and that they are her daughters, spirited away to be kept safe during their mother's long English captivity. "Your mother lives, but not for you» Mrs. Marlow tells the dumbfounded girls, thus at once consoling them and filling them with desolation.

Mary's legacy - of sorrow and female disempowerment, of relegation to the private (the recess of Lee's title) - seems clear: no wonder her daughters are depressed. And Mary is here clearly an image of women's traditional exclusion from political life; she does not stand for herself at all but very much for her female readers. In any case, their discovery that they are Mary's daughters initiates a long and baroque series of misadventures that brings her fictive daughters to Elizabeth's court, into often torrid relationship with various historical figures, to Jamaica, and finally to France, where the surviving twin (the other has gone mad and killed herself) looks toward her own grave and at last puts down her pen. In all this time, her daughters see Mary herself only once, and then only through barred windows, as she is taking an airing in a nearby castle. «We wept» writes Matilda, the dominant twin, who also happens to resemble Mary exactly: 
we incoherently exclaimed - and striking ourselves against eagerly against he bars, seemed to hope some supernatural strength would break them. More afflicted at seeing her thus, than not seeing her at all, I neither could behold her for my tears, or resolve to lose a look by indulging them [...O] ur hands, which we had thrust, in supplication, through the bars, caught her attention. - She raised her fine eyes... to the window - I would have spoke, but my lips denied all utterance. Alas! that blessed, that benignant glance, was the first, the last, the only one we ever received from a mother. - When she withdrew her eyes, she carried my very soul with her. (Lee, i, p. 196-197)

As in the novel's first portrait of Mary Queen of Scots, the queen's image is reliably linked to a historical response to her. Yet the reality of this response lies in its admission that those who have it are, like Mary, now alienated from any possibility of self-utterance.

Lee's literary portraits of the Queen of Scot, in other words, draw on the positive dichotomy of her historical reputation but also give us protagonists who internalize that dichotomy, maintain it as ambivalence, and upon that negation, or recess, build a fiction of personal and political identity. In The Recess, Mary becomes the grounds of the heroines'sense of themselves both as historical agent and as coherent subjects (of, among other things, language itself). She also undermines those very grounds - the girls are of course inventions, and even within the terms of the novel, they feel themselves «cut from the chain of creation» (Lee, i, p. 14). Mary's reputation doesn't really matter to Lee - she is more saintly than otherwise, but the important thing is that she is eventually absorbed into selfconfirming - and self-eradicating - emotional response to her. Yet this response generates a new and perhaps even more demanding order of historical and political commentary.

Lee's was only the first in a long line of female-authored fictions of response to Mary, and there is a point to be made about the British women's special relationship to Mary Queen of Scots - the frequency with which it has been specifically female emotion and desire that fuse with Mary's image, and the disproportionate degree to which women have identified Mary's seeming status as a manipulated sign with their own cultural invisibility and with insight into the kinds of denial and deception that underwrite political identity and historical confidence. «There is no odds that I can spy, / Twixt mary Queen of Scots and I» wrote a female working-class poet of the 
18th century, Mary Leapor, who came to this ungrammatical but arresting conclusion while contemplating her own gravestone (Leapor, 1748-1751, i, p. 41). The sub-history of female response to Mary that we find in her work and Lee's epitomizes and catalyzes the revision of her fractured reputation as a source of identificatory attachment grounded in unique historical awareness.

For instance, in Penelope Lively's Moon Tiger (1986), the heroine recalls a girlhood history lesson. While dutifully copying down the names and dates of English history, she hears her teacher praise Elizabeth's beheading of Mary Stuart:

I put up my hand: «Please Miss Lavenham, did the Catholics think she was right to cut off Mary's head?» « No, Claudia, I don't expect they did.» «Please, do Catholic people think so now?» Miss Lavenham took a breath: «Well, Claudia» she said kindly. «I suppose some of them might not. People do sometimes disagree. But there is no need for you to worry about that. Just put down what is on the board. Make your headings nice and clear in red ink...» And suddenly for me the uniform grey pond of history is rent; it is fractured into a thousand contending waves; I hear the babble of voices. I put my pen down and ponder; my headings are not nice and clear in red ink; I get $38 \%$ (Fail) in the end of term exams. (Lively, 1988, p. 14-15)

Claudia's « failure » to enter one kind of history is the condition of her entrance into a very different one, one which both assimilates and transcends the battle of reputations Miss Lavenham attempts to exploit in the interest of a conventional history lesson.

We saw at the outset that Mary Queen of Scots foregrounds the problem of reputation as a guide to historical knowledge: because she has more than one reputation, and because those reputations compete with one another, they tend to cancel each other out. But as we've now seen the problem of reputation that Mary really raises is more complicated than that: by inviting sympathetic identification in excess of reputation, Mary also undermines reputation's authority, detaching moral value from emotional power in such a way as to carry us beyond the nascent political, national and linguistic boundaries her very existence once challenged. Today, Mary's reputation is still unstable if we insist on thinking in moral, national or political terms. Even if we want to write a history of culture, we are hard-pressed to fix her anywhere. Who can say whether she was 
«a bad woman» or not, a mere «French girl» or not? The categories persist but «Mary Queen of Scots» also overrides them, bound to her beholder's tangled longing both to be in history and to escape it, to write history and yet to redefine what it means to do so. It may be Mary's singular fate to give such longings a face, if not a reputation or a name.

\section{Bibliography}

Anderson W.F.K. ed., The Journal of Sir Walter Scott, Oxford, 1977.

Bolton H.P. ed., Scott Dramatized, London, 1992.

Bredley K. and Cooper E., The Tragic Mary, London, 1890.

Brodsky J, Urania, London, 1991.

Buchanan G., A Detection of the Actions of Mary, Queen of Scots, 1587, London, 1721.

Camden W., Annals, or the History of the Actions of Mary, Queen of Scots, 1571, London, 1721.

Campbell H., Love Letters of Mary Queen of Scots to James, Earl of Bothwell, London, 1824.

Chambers R., Biographical Dictionary of Eminent Scotsmen, 4 vols., Edinburgh, 1835.

Donaldson G., All the Queen's Men: Power and Politics in Mary Stewarts's Scotland, London, 1983.

Esher V., ed., The Girlhood of Queen Victoria: A Selection from her majesty's Diaries Between the Years 1832 and 1840, 2 vols., London, 1912.

Froude J.A., The History of England, 12 vols., London, 1862.

Goodall W., An Examination of the Letters Said to be Written by Mary, Queen of Scots, Edinburgh, 1754.

Haywood E., Mary Stuart, Queen of Scots, Being a Secret history of Her Life and the Real Causes of All Her Misfortunes, London, 1725.

Hume D., History of England, London, 1778.

Jameson A., Memoirs of Celebrated Female Sovereigns, London, 1832.

Leapor M., Poems Upon Several Occasions, 2 vols., London, 17481751.

Lee S., The Recess: Or, A Tale of Other Times, 3 vols., 2 nd ed., London, 1786.

Leslie J., A Defence of the Honour of... Marie, London, 1569.

Lewis J.E., Mary Queen of Scots: Romance and Nation, London and New York, 1998. 
Lively P., Moon Tiger, New York, 1988.

Lynch M. ed., Mary Stewart, Queen in Three Kingdoms, Oxford, 1988.

Perry R. ed., Memoirs of Several Ladies of Great Britain, London, 1752.

Petti A.G., « Richard Verstegan and Catholic Martyrologies of the later Elizabethan Period », Recusant History, v, 1959-1960, p. 64-90.

Phillips J.E., Images of a Queen: Mary Stuart in Sixteenth-Century Literature, Berkeley and Los Angeles, 1964.

Robertson W., The History of Scotland During the Reigns of Queen Mary and King James VI, Edinburgh, 1759.

Scott W., The Abbot, 2 vols., London, 1820.

Smailes H. and Thomson D., The Queen's Image, Edinburgh, 1987.

Strickland A., Lives of the Queens of Scotland and English Princesses, 6 vols., London, 1844.

Tytler W., An Inquiry Historical and Critical into the Evidence against Mary Queen of Scots, London, 1759.

Wormald J., Mary Queen of Scots: A Study in Failure, London, 1988. Wyngfield R., "An Account of the Execution of Mary, the Late Queen of Scots (1587) ", in The Clarendon Historical Society Reprints, series II, 2 vols., Edinburgh, 1884-1886. 